\title{
The Short Comment on the Journal “Artoaj”, vol. 15, II Edition
}

\author{
Demur Chomakhidze* \\ Department of Georgian National Energy Regulatory Commission, Georgia
}

Submission:May 13, 2018; Published: June 05, 2018

"Corresponding author: Demur Chomakhidze, Department of Georgian National Energy Regulatory Commission, 19, A. Mitskevichi Str., Tbilisi, 0194, Georgia, Email: demurchomakhidze@yahoo.com

\section{Commentary}

The mentioned above edition presents numerous urgent topics, they are really dedicated to the important agricultural problems and definitely deserve approval from readers. However, I have an impression that the issues related to energy efficiency of the field are not discussed appropriately. These problems are actual for all countries.

Below I'll try to present energy efficiency issues through the examples of my country. It will be preferable if the journal covers the given themes, in this way it will boost its rating among readers.

Energy saving is one of today's most urgent problems, and it is particularly acute in Georgia. The republic is not rich in energy resources, so in order to satisfy its economy's demand for them, a large amount of energy is imported. This includes the entire volume of natural gas consumed, most of the oil and petroleum products, and a large percentage of electricity. What is more, Georgia far from uses its energy resources rationally; in particular, there is frequently a noticeable lag in the country's energy efficiency indices behind similar parameters of developed countries.

During the years of Soviet power, an average of almost 900 million rubles in energy resources was expended in Georgia's material production per year. These expenditures were particularly high in industry - this sector accounted for $71 \%$ of all the expenditures in the material production sphere.

The expenditures of energy resources were high in the ferrous metallurgy, chemical, and petrochemical industries. Whereas an average of 15.7 kopeks per ruble of pure product was spent in industry, this index reached 16.2 kopeks in ferrous metallurgy and almost 18 kopeks in the building material sector.

These expenditures were relatively small in agriculture and construction, which shows the low level of energy supply in these industries.
Research has shown that at this stage of development, the value of Georgia's energy resources noticeably exceeded the role of labor productivity. In particular, each percent of fuel and energy resources saved in ferrous metallurgy was more significant (1.3-fold) than the percentage of increase in labor productivity. Estimates show that in 1988 an increase in labor productivity in this industry by $1 \%$ made it possible to obtain 815.000 rubles in pure product, while a drop in the energy-output ratio by $1 \%$ made it possible to save 1.069 .000 rubles, or $31.2 \%$ more. The importance of energy resource saving increased even more during Georgia's independence. This was promoted by the fact that the country's economy became dependent mainly on the import of energy resources. Consequently, whereas in 1988 the value of a drop in the product energy-output ratio was higher than the value of an increase in labor productivity by $31.2 \%$, as early as 2000 , this index amounted to $76.2 \%$. This index increases even more if production is expanded. It has been proven that the value of fuel and energy resource saving as a source of the republic's economic growth increases as production expands and intensifies. Based on the specific materials the impact of the public labor fruitfulness and energy saving is compared to the volume of the Whole Inside Product (WIP). It is said, that the reduction of the energy volume of WIP on $1 \%$ is giving approximately the same and in separate years even more effect in the augment of the volume of the WIP, compared to the rising the public labor productivity in the same way.

Energy resource saving makes it possible to reduce capital investments in raw material extraction and equipment manufacture for primary production, while the resources saved can be used to meet the social needs of the population.

It stands to reason that significant saving of fuel and energy resources, in the same way as their production, requires certain expenditures. So would it not be better to use the funds expended on ensuring fuel and energy resource saving to increase their production? This question does not have an affirmative answer. 
a. First, even if fuel and energy reserves were not limited, their increased reproduction is not justified from the economic viewpoint. Calculations have confirmed that in order to carry out large-scale-energy-saving measures, 2-3 fold fewer investments are required than to produce fuel and energy resources in equivalent volumes.

b. Second, practice shows that an increase in the production of fuel and energy resources aggravates the shortage of these and other resources to a certain extent. This is due to the fact that primary production is a capital and labor-intensive industry, and its development requires large amounts of machinery, equipment, materials, and energy, as well as manpower. On the other hand, there is rapidly growing need for these resources in the economic sphere, but meeting it only in an extensive way is not only inefficient, but also impossible.

At present (2017), saving fuel and energy resource consumption in Georgia of $1 \%$ means saving approximately 48,000 tones of oil equivalent, including 110 million $\mathrm{kWh}$ of electricity, $23 \mathrm{~m} \mathrm{~cm}$ of natural

gas, and so on. Most of the electric power consumed is expended in the municipal and household sector. In 2017, it amounted to almost 5 billion $\mathrm{kWh}$, which is much more than the amount manufactured at Georgia's largest Inguri hydropower plant. A drop in electric energy consumption in this sector by $1 \%$ using the available reserves will make it possible to save almost 50 million kWh.
Your next submission with Juniper Publishers will reach you the below assets

- Quality Editorial service

- Swift Peer Review

- Reprints availability

- E-prints Service

- Manuscript Podcast for convenient understanding

- Global attainment for your research

- Manuscript accessibility in different formats

( Pdf, E-pub, Full Text, Audio)

- Unceasing customer service

Track the below URL for one-step submission https://juniperpublishers.com/online-submission.php 